\title{
Wielka Nowenna Milenijna a recepcja Vaticanum II w katolickim Kościele w Polsce
}

\section{Refleksja wstępna}

Vaticanum II i sprawa jego recepcji to temat nieustannie aktualny w wymiarze Kościoła in orbe terrarum ${ }^{1}$. Także i w odniesieniu do Kościoła katolickiego w Polsce ujawnia nie tylko bezbrzeżną wprost tematyczną bibliografię, ale także, co jest istotne, jego aktualną kondycję życia wewnętrznego, jak i miarę skuteczności dawania świadectwa na obszarze swego posługiwania ${ }^{2}$. W opracowaniach wskazuje się na różnorodne oddziaływania i na takie czy inne skutki recepcji.

Niniejsze ujęcie jest próbą ukazania, choćby w postaci przypomnienia, wpływu Wielkiej Nowenny na odbiór i przyswojenie wskazań Vaticanum II w Polsce.

1 Wiele o recepcji Vaticanum II w różnych krajach świata zob. Studia Soborowe. Historia i recepcja Vaticanum II, red. M. Białkowski, t. 1, Toruń 2014, s. 776; t. 2, Toruń 2015.

2 Na szczególne wspomnienie zasługuje monumentalna seria $W$ nurcie zagadnień posoborowych, I-XX, Warszawa 1967-1995, wydawana pod redakcją ks. bp. Bogdana Bejze (1929-2005). Zob. też praca zbiorowa Idee przewodnie soborowej konstytucji o Kościele, Kraków 1971; por. także A. Kubiś, Vaticanum II - wydarzenie i dzieło, „Analecta Cracoviensia” XIX (1987), s. 459-470. 
Temat zamierzonego rozważania obejmuje czas od zapowiedzi zwołania II Soboru Watykańskiego 25 stycznia 1959 roku przez papieża Jana XXIII do nadzwyczajnego Synodu Biskupów w Rzymie, zwołanego przez papieża Jana Pawła II na jesieni 1985 roku, w dwudziestolecie zakończenia Soboru, dla przyjrzenia się aktualności jego ustaleń w życiu Kościoła. W 1957 roku rozpoczęła się w Kościele katolickim w Polsce Wielka Nowenna przed Millennium Chrztu Polski, której treść i owoce były ściśle powiązane z życiem i wydarzeniami Kościoła powszechnego tego czasu. „Polską" datą końcową, przyjętą w niniejszym tekście, będą wskazania z sesji naukowej 28 listopada 1985 roku, jaka odbyła się na Papieskim Wydziale Teologicznym w Krakowie, a odnosiła się do tematyki wspomnianego synodu w Rzymie. Wspomniana „polskość” recepcji Vaticanum II będzie w tym omówieniu zawężona do spraw wynikających z wydarzenia Wielkiej Nowenny, która stanowi ważny, a dotąd mało przypominany fakt.

Zgodnie z przyjętym planem rozważań (1) zatrzymamy się najpierw na treści Wielkiej Nowenny, (2) następnie przypomnimy świadomość wiernych Kościoła w Polsce dotyczącą Soboru w czasie jego trwania, (3) by przyjrzeć się praktycznej stronie stosowania w duchu i w literze jego wskazań i (4) zatrzymać się nad dylematami w tzw. reformie liturgicznej; (5) finałem tych rozważań będzie mariologiczny wątek, który w soborowym wezwaniu „Matka Kościoła” podkreśli specyfikę teologicznego i duszpasterskiego wysiłku Kościoła w Polsce tak mocno zaakcentowanego w Wielkiej Nowennie.

\section{Wielka Nowenna przed Millennium}

Kościół katolicki w Polsce po drugiej wojnie światowej znalazł się w całkowicie nowej sytuacji. Z jednej strony towarzyszył swoim wiernym w przywracaniu pokoju i zgody w nowych granicach państwa, a także podejmował dzieło integracji wielkiej kilkumi- 
lionowej emigracji i wspomagał podczas repatriacji mieszkańców ziem wschodnich na tzw. ziemiach odzyskanych. Z drugiej zaś strony, boleśnie doświadczony wydarzeniami wojny światowej, stanął wobec usiłowań dążących do jego podporządkowania i zniszczenia ze strony narzuconego systemu ateistycznego w wydaniu stalinowskiego marksizmu. Sprawy te są dziś powszechnie znane dzięki bogatej literaturze naukowo-historycznej.

Jedną z form obrony i mobilizacji wiernych było zbiorowe wyznawanie i przeżywanie wiary pod przewodnictwem biskupów. Dbali o to, tworząc konkretne programy duszpastersko-duchowe, szczególnie prymasi August Hlond i Stefan Wyszyński. Do takich dzieł trzeba zaliczyć w 1946 roku: 7 lipca poświęcenie rodzin i parafii Niepokalanemu Sercu Maryi, 15 sierpnia - diecezji, a pod przewodnictwem prymasa kard. Augusta Hlonda na Jasnej Górze 8 września - całego narodu z udziałem około miliona pątników. Prymas kard. Stefan Wyszyński, nawiązując do 300. rocznicy maryjnych ślubów króla Jana Kazimierza z 1656 roku, podczas swego internowania (1953-1956) napisał tekst ślubów na dzień 26 sierpnia 1956 roku do odczytania ich na Jasnej Górze. Obmyślił też Wielką Nowennę do Matki Bożej (1957-1966) z okazji zbliżającego się Millennium Chrztu Polski ${ }^{3}$. Jej szczególnym znakiem stała się peregrynacja kopii obrazu Matki Boskiej Częstochowskiej po wszystkich diecezjach i parafiach ${ }^{4}$. Historyk, a równocześnie uczestnik tego wydarzenia

3 Por. J. Zawadka, Wielka Nowenna w koncepcji duszpasterskiej Prymasa Wyszyńskiego. Zarys problematyki pastoralno-historycznej, „Warszawskie Studia Teologiczne” XXIV/1 (2011), s. 243-254; A. Skreczko, Wybrane przejawy troski Kościoła katolickiego o rodzinę $w$ Polsce, „Studia nad Rodziną" (UKSW) 13 (2009) 1-2 (24-25), s. 130nn.

4 Por. M. Banaszak, Historia Kościoła katolickiego, t. 4: Czasy najnowsze 1914-1978, Warszawa 1992, s. 295. Peregrynacja kopii cudownego obrazu Matki Bożej Częstochowskiej, związana z Wielką Nowenną, ze względu na liczbę parafii i ośrodków duszpasterskich w Polsce, zakończyła się w pierwszym etapie dopiero 12 października 1980 roku. 4 maja 1985 roku rozpoczął się drugi etap tej peregrynacji, który dalej 
tak o tym pisze: „Gigantyczne wręcz, bez żadnej przesady, rozmiary akcji społecznej przybrała podjęta z inicjatywy prymasa [kard. Stefana Wyszyńskiego] 3 maja 1957 roku na Jasnej Górze Wielka Nowenna Milenijna przygotowująca tysiąclecie chrztu Polski w 1966 roku. Kopia obrazu Matki Boskiej Jasnogórskiej w uroczystej procesji obeszła wówczas wszystkie parafie kraju, przy czym wysiłek ogółu wiernych dla nadania tej wizycie charakteru możliwie uroczystego, widowiskowego, był wszędzie wręcz niezwykły; wszystkie świadectwa zgodne są też w podkreślaniu wagi i głębokości przeżyć religijnych związanych z «wizytą» i towarzyszącymi jej misjami-rekolekcjami. Przyszłe badania wykażą, jak wielkie - nie ma co do tego wątpliwości! - miało to znaczenie w całym kontekście przemian zachodzących w społeczeństwie polskim w latach 1957-1966”5.

Forma nowenny ze względu na długi okres jej oddziaływania pozwalała na wszechstronną katechizację narodu, polegającą na przypomnieniu treści ewangelicznych, przeprowadzeniu indywidualnego i społecznego rachunku sumienia i powrotu na drogę życia według Ewangelii. Program Wielkiej Nowenny obejmował dziewięć lat z odpowiednio dobranymi tematami na każdy rok:

- 1957/58: „Wierność Bogu, Krzyżowi, Ewangelii, Kościołowi i jego Pasterzom”,

- 1958/59: „Naród wierny łasce”, życie w łasce Bożej i przeciwstawianie się każdemu grzechowi,

- 1959/60: „Życie jest światłością ludzi”, rok życia, obrona życia duszy i ciała,

- 1960/61: „Małżeństwo, sakrament wielki w Kościele”,

trwa i niesie w nowym czasie idee Wielkiej Nowenny, por. https://pl.wikipedia.org/wiki/Kopia_obrazu_Matki_Boskiej_Częstochowskiej [data dostępu: 31.07.2019].

5 J. Kłoczowski, L. Müllerowa, W dwudziestym stuleciu (1918-1980), w: Zarys dziejów Kościoła katolickiego w Polsce, Kraków 1986, s. 401402; por. Z. Zieliński, Wielka Nowenna, w: Encyklopedia katolicka, t. XX, Lublin 2014, kol. 496-497. 
- 1961/62: „Rodzina Bogiem silna”, wychowanie w duchu Chrystusowym,

- 1962/63: „Młodzież wierna Chrystusowi”,

- 1963/64: „Abyście się społecznie miłowali”, sprawiedliwość i miłość społeczna,

- 1964/65: „Nowy człowiek w Chrystusie”, walka z wadami narodowymi, pielęgnowanie cnót chrześcijańskich i narodowych,

- 1965/66: „Weź w opiekę Naród cały”, cześć Maryi jako Królowej Polski ${ }^{6}$.

O treści rocznych tematów tej akcji duszpasterze byli informowani w nielicznych wtedy pasterskich listach biskupów ${ }^{7}$, które tylko pośrednio nawiązywały do tematów Wielkiej Nowenny ${ }^{8}$. Szczegółowe materiały - także te oficjalnie niepublikowane były dostępne w kuriach diecezjalnych, przekazywane na duszpasterskich spotkaniach kapłanów w dekanatach czy rejonach, a także w kazaniach w „Nowej Bibliotece Kaznodziejskiej”.

6 Wyczerpujące omówienie idei Wielkiej Nowenny i jej aktualności prezentuje ks. Jan Siedlarz, Wielka Nowenna Tysiąclecia - program społeczny na dziś, „Currenda. Pismo Urzędowie Diecezji Tarnowskiej”, październik-grudzień 2001, http://centrumzawierzenia.jasnagora.pl/2015/05/ wielka-nowenna-tysiaclecia-program-spoleczny-na-dzis-ks-dr-jansiedlarz/ [data dostępu: 3.06.2019].

$7 \quad \mathrm{Z}$ powodu ingerencji cenzury państwowej biskupi polscy nie mogli w oficjalnych pismach przedstawiać całościowo rocznych tematów Wielkiej Nowenny. Czynili to w swoich listach pośrednio, bez wyraźnego odwołania się do tej akcji duszpasterskiej. Otwarcie mogli to uczynić dopiero na rozpoczęcie ósmego i dziewiątego roku Wielkiej Nowenny, por. Listy pasterskie Episkopatu Polski 1945-1974, Paris 1975 [dalej: LPEP], s. 350-354 (3.05.1964) i 393-399 (12.03.1965).

8 Przykładem może tu być list pasterski Episkopatu Polski na Wielki Post roku 1960, który nie ma swego tematu, a w którym jest wzmianka o przeżywanym „Roku życia” i o obronie dzieci nienarodzonych, zob. LPEP, s. 191. Podobnie jest na czwarty rok Wielkiej Nowenny w liście biskupów O sakramencie małżeństwa, dotyczącym tematu na rok 1960/1961, zob. LPEP, s. 215nn. 
Jeden ze świadków tego etapu życia i posługi Kościoła w Polsce pisze: „Był to czas gigantycznej pracy Kościoła w Polsce, najpierw trud organizacji katechizacji, która musiała być organizowana poza szkołą, następnie wysiłek objęcia katechezą jak największej liczby dzieci i młodzieży. Kościół w Polsce czasu przełomu lat pięćdziesiątych i sześćdziesiątych XX wieku podjął ogromny trud realizacji założeń Wielkiej Nowenny przed Millennium Chrztu Polski, której program i treść w dużym stopniu pochodziła z myśli i duchowości Sługi Bożego kardynała prymasa Stefana Wyszyńskiego. Wysiłek duszpasterski i homiletyczny Kościoła w Polsce był programowany w tamtych czasach głównie z perspektywy tematyki Wielkiej Nowenny. To było przedmiotem zainteresowania i troski duszpasterskiej Kościoła w Polsce w czasie, gdy przygotowano Sobór, a także wtedy, gdy on trwał [...]. Kościół w Polsce koncentrował się na przekazie wiary, obronie przed naciskiem planowanej ateizacji społeczeństwa, obronie małżeństwa i rodziny, obronie przed kłamliwą ideologią przekazywaną w systemie edukacji na wszystkich jej stopniach oraz dyskryminacji ludzi wierzących. Duszpasterstwo było nastawione na masowego odbiorcę, co wzmacniało tzw. ludową religijność, ściśle związaną z różnymi formami obyczajowości [...]. Można dziś z perspektywy czasu powiedzieć, że mimo nacisku ideologicznego związanego z programem ateizacji społeczeństwa i dyskryminacji ludzi wierzących, ofiarna praca Kościoła w Polsce, opór społeczeństwa, które broniło się przed totalitaryzmem ideologicznym, ocaliła wiele wartości, które pomagały przetrwać lata prześladowań i cierpień. Co więcej, Kościół, który tak samo jak wielu ludzi był prześladowany i ograniczany w swej działalności, zyskał niezwykły autorytet" ${ }^{\prime}$.

9 J. Bagrowicz, Recepcja Soboru Watykańskiego II w Polsce - zagadnienia wybrane. Refleksje bardzo osobiste, w: Studia Soborowe, s. 584-585. 


\section{Sobór Watykański w świadomości katolików w Polsce}

Wzajemne oddziaływanie wspomnianej Wielkiej Nowenny i II Soboru Watykańskiego stało się oczywiste. Chodzi bowiem najpierw o ich zbieżność czasową. Polscy ojcowie soborowi z prymasem kard. Stefanem Wyszyńskim na czele byli zarazem promotorami dzieła i nabożeństw Wielkiej Nowenny. Można powiedzieć, że wieści o kolejnych etapach Soboru, podawane nade wszystko przez polskich biskupów, stały się w dziele Wielkiej Nowenny, w jej przebiegu jakby jej integralną częścią. I już na tym etapie podczas trwania Vaticanum II można mówić o jego swoistej recepcji w katolickim Kościele w Polsce.

Już kilka miesięcy po zapowiedzi zwołania Soboru, 17 czerwca 1959 roku, biskupi polscy skierowali wezwanie $W$ sprawie przyszłego soboru powszechnego. Wyrazili w nim nadzieję na zjednoczenie Kościoła Chrystusowego i umocnienie wiary. Wezwali też do podjęcia modlitw wskazanych przez papieża Jana XXIII i za wstawiennictwem Matki Najświętszej ${ }^{10}$.

W orędziu Episkopatu Polski na styczeń 1962 roku (podpisanym 16 listopada 1961) do odczytania w trzecią rocznicę zwołania Vaticanum II jest obszerna informacja na temat znaczenia Soboru w Kościele, aktualnych przygotowań i porządkowania materiałów, a także o oczekiwaniach na jego owoce w Kościele. Jest też „wezwanie: Niechaj i z polskiej ziemi wyciągają się do Boga ręce modlitewne i pomocne, współpracujące w wielkim dziele zbliżającego się Soboru Powszechnego"11. Przed wyjazdem na otwarcie Soboru biskupi polscy w liście z 30 września 1962 roku zwrócili się z prośbą o nieustanną modlitwę w jego

10 Por. Wezwanie Episkopatu Polski „W sprawie przyszłego Soboru Powszechnego", w: LPEP, s. 183.

11 LPEP, s. 237-241. Wspomniane orędzie biskupów jest dobrym źródłem do uświadomienia sobie świadomości eklezjalnej w Kościele katolickim w Polsce w przededniu Vaticanum II. 
intencji. Najbardziej znaną - pośród wielu innych modlitw i dzieł soborowych - było Czuwanie soborowe z Maryja Jasnogórską, które objęło wszystkie diecezje Polski ${ }^{12}$.

Rok 1963 przyniósł wiernym w Polsce kolejne istotne treści związane z przebiegiem trwającego Vaticanum II. W liście pasterskim biskupów polskich, który można nazwać sprawozdaniem po pierwszej sesji Soboru (styczeń 1963), możemy przeczytać, „że i przez Kościół katolicki w Polsce w ślad za zwołaniem Soboru powiał ożywczy duch nowego życia”. Stało się to okazją „do głębszego poznania Kościoła jako społeczności powszechnej i jego szczytnego zadania". Dla młodzieży, którą obejmował w tym czasie roczny temat Wielkiej Nowenny, wspomniany Sobór może być „wspaniałą lekcją poglądową żywotności Kościoła” dla pełnej wierności Chrystusowi. „Nade wszystko biskupi dziękują za błogosławieństwo "czuwań soborowych», w których uczestniczyły wielkie rzesze wiernych w całej Polsce, a poprzez to pogłębiły świadomość łączności z wydarzeniami w Kościele powszechnym"13.

12 Por. List Episkopatu Polski do duchowieństwa i wiernych „Przed wyjazdem na Sobór Watykański Drugi”, w: LPEP, s. 274-278. Dla przykładu warto wspomnieć, że w ramach wspomnianego „czuwania soborowego z Maryją Jasnogórską" podczas trwania pierwszej sesji Soboru (11.10-8.12.1962) w każdej parafii odbywały się nabożeństwa według ułożonego kalendarza. Każdego dnia w ok. 40 parafiach Kościoła katolickiego w Polsce odbywały się msze św. i modlitwy na intencję Soboru przez całą dobę. Była też prośba biskupów o włączanie intencji soborowych na nabożeństwach różańcowych w październiku 1962 roku i organizowanie odpowiednich nabożeństw z pouczeniami o Soborze, por. także: B. Kumor, Historia Kościoła, cz. 8: Czasy wspótczesne 1914-1992, Lublin 1995, s. 560.

13 „Niewątpliwie, dla nas, biskupów polskich, było wielką pociechą, że Polska się modliła. Dowiedzieliśmy się z tysiącznych listów, że Polska czuwa z Panienką Jasnogórską, a odbywając w parafiach «czuwanie soborowe» wysyła przedstawicieli na Jasną Górę. Delegacje te ze świecą czuwania stoją przed cudownym obrazem Matki Boskiej Częstochowskiej i modlą się w intencji Soboru. Taką świecę, powstałą z wosku niedopalonych świec czuwania, przywiezionych przez poszczególne parafie Polski, 
Przed wyjazdem na drugą sesję Soboru biskupi skierowali do wiernych kolejną prośbę. Chodziło o podjęcie „soborowego czynu dobroci” (Jasna Góra, sierpień 1963) ${ }^{14}$. „Jest to - napisali biskupi - dojrzalsza i trudniejsza forma wspierania Kościoła, bo wkracza w bardzo delikatną, niełatwą dziedzinę współżycia między ludźmi. Wymaga wielkiej ofiary i przezwyciężania siebie dla jedności i miłości Chrystusowej”"15. Po szerokim omówieniu proponowanej formy pomocy dla Soboru dodali: „«Soborowy czyn dobroci» wiąże się ściśle z programem siódmego roku Wielkiej Nowenny, pod hasłem «Sprawiedliwość z miłością zaślubiona». Łączy się też z tegorocznym Tygodniem Miłosierdzia, który wzywa wszystkich katolików do czynnej miłości braci [...]. Wasze dobre czyny zapisywać będziecie do «Parafialnej księgi soborowych czynów dobroci»". Zapisaną czynami ofiarowanymi za Sobór księgę parafie zawiozą na Jasną Górę ${ }^{16}$.

Powyższą prośbę o soborowy czyn dobroci i nieustanną modlitwę powtórzyli polscy biskupi w słowie pasterskim z Rzymu 29 września, w święto Michała, Gabriela i Rafała, archaniołów, $w$ dniu rozpoczęcia drugiej sesji Soboru. Znamienne są tutaj m.in. słowa wyznania biskupów, że choć Sobór jest przede wszystkim sprawą biskupów obradujących pod kierownictwem Ojca

wręczyliśmy Ojcu świętemu [papieżowi Janowi XXIII] w czasie naszej pożegnalnej audiencji jako wspaniały dokument modlącej się Polski w intencji Ojca świętego i Soboru. Świecę tę polecał zapalać w swojej kaplicy, kiedy odprawiał Przenajświętszą Ofiarę. "Czuwania soborowe» przeprowadzone w każdym zakątku Polski, skoncentrowane przed obrazem Jasnogórskiej Królowej, przeszły wszelkie nasze oczekiwania, stały się prawdziwą łaską nieba okazaną naszemu ludowi i silnym węzłem wiążącym nas z Kościołem Powszechnym i jego Głową. Czuwania te są błogosławionym owocem łaski, płynącej z Kościoła Bożego w historycznym roku Soboru” (List pasterski Episkopatu Polski do wiernych „Po pierwszej sesji Soboru Watykańskiego Drugiego”, w: LPEP, s. 286-287).

14 Por. Episkopat Polski wzywa wiernych do Soborowego czynu dobroci, w: LPEP, s. 321-325.

15 Tamże, s. 321.

16 Tamże, s. 325. 
Świętego, to „łatwo odkrywamy, że Sobór jest również sprawą całego Ludu Bożego. Wszyscy wierni stają się za Sobór współodpowiedzialni" ${ }^{17}$. Do tego listu dołączono bogaty wybór intencji soborowych. Jest to propozycja w liczbie 115 tematów do wykorzystania na nabożeństwach w intencji Soboru. Intencje te podzielone są na dziewięć rozdziałów: (1) Sobór [1-4], (2) Kościół [5-29], (3) osobowość chrześcijańska, życie liturgiczne, apostolstwo [30-47], (4) bracia niekatolicy [48-64], (5) biskupi - kapłani [65-84], (6) zakony [85-89], (7) małżeństwo, życie rodzinne [90-97], (8) młodzież, wychowanie i katechizacja [98-105], (9) miłość i sprawiedliwość społeczna [106-115] ${ }^{18}$. W treści tychże intencji, które w swojej istotnej wartości domagają się osobnego omówienia, można wyczytać oczekiwania polskich biskupów w stosunku do obradującego Soboru, które też polecili modlitwom wiernych.

Dyskusja podczas drugiej sesji Soboru nad schematem „O Kościele" była z pewnością dynamicznym doświadczeniem, skoro podczas jej trwania (27 października 1963) polscy biskupi skierowali kolejne przesłanie pt. Polscy ojcowie soborowi do świętego Kościoła Chrystusowego w Polsce ${ }^{19}$. Pozytywnie wspomnieli o różnych wiadomościach dochodzących do Polski z Rzymu i auli soborowej ${ }^{20}$. Znamienne były ich odczucia, doświadcze-

17 Słowo pasterskie biskupów polskich „W dniu wznowienia obrad Soboru Watykańskiego Drugiego" (29.09.1963), w: LPEP, s. 326.

18 Por. Intencje soborowe, w: LPEP, s. 328-333.

19 Por. Polscy ojcowie soborowi do świętego Kościoła Chrystusowego w Polsce, w: LPEP, s. 334-336.

20 Por. tamże, s. 336. Jest to osobny wielki temat o interpretacji Soboru podczas jego trwania przez różne środowiska Kościoła katolickiego, jak też i spoza niego - sobór poza aulą soborową - artykułujące raczej swoje oczekiwania, nierzadko inne niż te od ojców soborowych. Po zakończeniu trzeciej sesji Soboru biskupi polscy nie byli już tak optymistyczni i przestrzegali przed rozpowszechnianiem wiadomości na temat Soboru, zwłaszcza tych, które wiązały się z pytaniem, jakie zmiany wprowadzi Sobór?, a nie z tym, jak ma wyglądać „odnowa w Kościele”, por. List pasterski biskupów polskich „Po zakończeniu trzeciej sesji Soboru Watykańskiego Drugiego", w: LPEP, s. 368n. 
nie i recepcja treści z tychże obrad, skoro pisali: „Tajemnica Mistycznego Ciała Chrystusowego każe nam patrzeć dalej. Sięgać do dusz innych chrześcijan, naszych braci odłączonych, oraz do dusz wyznawców religii niechrześcijańskich i wreszcie - do dusz wszystkich ludzi. Wszędzie gdzie może znajdować się bodaj okruszyna prawdy, wszędzie gdzie można odczuć jakieś wezwanie łaski - tam dociera Sobór ze swoją myślą o rodzinie ludzkiej i o Mistycznym Ciele Chrystusa. I zaprawdę czujemy, że nadeszła w dziejach ludzkości godzina po temu, aby Boża prawda o Kościele stanęła na oczach ludzkości w całej swej głębi i dojrzałości. Przygotował nas do tego już Sobór Watykański Pierwszy przed stu prawie laty, ale Sobór obecny musi to dzieło doprowadzić do końca" ${ }^{21}$. Z racji uchwalonej na tejże sesji soborowej 4 grudnia 1963 roku Konstytucji o liturgii świętej, której wskazania miały obowiązywać w Kościele od 14 lutego 1964 roku, tj. od pierwszej niedzieli Wielkiego Postu, biskupi polscy opublikowali dwa listy pasterskie $\mathrm{z}$ datą na oktawę Wielkanocną 1964 roku. W liście do wszystkich wiernych ${ }^{22}$ po omówieniu soborowego zamysłu reformy w liturgii Kościoła, u której początku była sprawa używania języków narodowych, napisali: „Jedno pragniemy przypomnieć w naszym liście: konieczność Waszego udziału w tym wielkim i ważnym dziele, które wymaga pewnego starania i wysiłku ze strony wszystkich członków Kościoła katolickiego, a więc i ludzi świeckich. Jest gorącym pragnieniem Soboru, wyraźnie w kilku miejscach konstytucji podkreślone, by wierni z należytym usposobieniem duchowym uczestniczyli czynnie, świadomie i z pobożnością w obrzędach liturgicznych, jakie są odprawiane w naszych świątyniach"23. Razem ze wspomnianym

${ }^{21}$ Polscy ojcowie soborowi do świętego Kościoła Chrystusowego w Polsce, w: LPEP, s. 336.

${ }^{22}$ List pasterski biskupów polskich „Z okazji wejścia w życie soborowej konstytucji o świętej liturgii”, w: LPEP, s. 339-344.

23 Tamże. Z pewnością chodzi szczególnie o następujący soborowy zapis: „Kościół zatem bardzo się troszczy o to, aby chrześcijanie w tym mi- 
listem do wszystkich wiernych biskupi skierowali przesłanie do duchowieństwa, od którego zaangażowania zależał los tej refor$\mathrm{my}^{24}$. W odwołaniu się do ważności liturgii jako najłatwiejszego i najpewniejszego środka wiodącego człowieka do jego upodobnienia się do Chrystusa i do zjednoczenia z Bogiem, wobec nieufności wielu zauważyli z naciskiem, że tekst Konstytucji o liturgii świętej to dzieło dobre, otwierające szerokie perspektywy do ożywienia życia religijnego. Z przekonaniem napisali: „Od nas teraz zależy, żeby wykonanie tego prawa było i dokładne i pełne, a gdy o nas kapłanów chodzi, z całą gorliwością i zapałem spełnione. Przekonamy się po paru latach, że to dzieło Soboru będzie miało w swych skutkach bardzo wielkie znaczenie dla Kościoła katolickiego"25.

Ósmy rok Wielkiej Nowenny, rozpoczęty 3 maja 1964 roku pod hasłem: "«Nowy człowiek w Chrystusie», walka z wadami narodowymi, pielęgnowanie cnót chrześcijańskich i narodowych"26, został powiązany z kolejnym wezwaniem biskupów polskich do ofiarowania w intencji Soboru - tym razem wysiłku nad pokonaniem wad narodowych i troski o rozkwit cnót chrześcijańskich ${ }^{27}$. Napisali: „Sobór Watykański Drugi ukazuje

sterium wiary nie uczestniczyli jak obcy lub milczący widzowie, lecz aby przez obrzędy i modlitwy misterium to dobrze rozumieli, w świętej czynności brali udział świadomie, pobożnie i czynnie, byli kształtowani przez słowo Boże, posilali się przy stole Ciała Pańskiego i składali Bogu dziękczynienie; aby ofiarując niepokalaną Hostię nie tylko przez ręce kapłana, lecz także razem z nim, uczyli się ofiarowywać samych siebie i za pośrednictwem Chrystusa $\mathrm{z}$ każdym dniem doskonalili się w zjednoczeniu z Bogiem i wzajemnie ze sobą, aby ostatecznie Bóg był wszystkim we wszystkich" (KL 48).

${ }^{24}$ Biskupi polscy do duchowieństwa „W zwiq̨zku z wejściem w życie konstytucji soborowej o świętej liturgii”, w: LPEP, s. 345-349.

25 Tamże, s. 349.

26 Por. List biskupów polskich na rozpoczęcie ósmego roku Wielkiej Nowenny „O nowym człowieku w Jezusie Chrystusie”, w: LPEP, s. 350-354.

27 Por. List pasterski Episkopatu Polski do duchowieństwa i wiernych „O zwycięstwo nad sobq na rzecz Soboru", w: LPEP, s. 359-363. 
światu drogi pełnego zwycięstwa Kościoła w prawdzie i miłości Chrystusowej. Sobór pragnie, aby Kościół święty ogarnął swymi ramionami wszystkie narody i zjednoczył je w Chrystusie. Do owego zwycięstwa Kościoła świętego pokornie pragnie przyczynić się Naród polski przez maryjny dar «Soborowego zwycięstwa nad sobą»" 28 .

Na zakończenie wspominanej powyżej trzeciej sesji Soboru w obszernym liście-sprawozdaniu ${ }^{29}$ biskupi polscy poinformowali o przyjęciu na nim nowych dokumentów, m.in. Konstytucji dogmatycznej o Kościele, po raz pierwszy w historii z pełną nauką o misterium Kościoła, dekretu o ekumenizmie i o katolickich obrządkach wschodnich. Nade wszystko przekazali wieść „o wydarzeniu najdonioślejszym i najbardziej radosnym, które miało miejsce podczas zamknięcia trzeciej sesji Soboru, 21 listopada w uroczystość Przedstawienia Najświętszej Maryi Panny w świątyni”, kiedy „Ojciec Święty [papież Paweł VI] w swym przemówieniu końcowym uroczyście ogłosił Najświętszą Maryję Pannę - Matką Kościoła, a w chwilę potem poświęcił cały rodzaj ludzki Jej Niepokalanemu Sercu"30. Tym samym biskupi mogli potwierdzić spełnienie prośby swego memoriału złożonego przed rozpoczęciem tejże sesji Soboru o potwierdzenie tego tytułu Maryi akceptacją całego zgromadzenia soborowego pod przewodnictwem Ojca Świętego. I dodali w tymże liście: „Opatrzność chciała, by to dziejowe wydarzenie, jaki jest Sobór Watykański Drugi, zeszło się w czasie z historyczną chwilą polskiego Millennium. Wszystko zdaje się wskazywać na to, że w ostatnim roku polskiego Millennium Sobór zakończy swe prace. Pod wspaniałymi zapowiedziami rozpoczniemy drugie tysiąclecie istnienia i pracy Kościoła w Polsce" ${ }^{31}$. W liście tym biskupi polscy zaznaczyli, jak

${ }^{28}$ Tamże, s. 363.

${ }^{29}$ List pasterski biskupów polskich „Po zakończeniu trzeciej sesji Soboru Watykańskiego Drugiego" (16.12.1964), w: LPEP, s. 367-373.

30 Tamże, s. 371.

31 Tamże, s. 373. 
wielkim wsparciem dla nich była też świadomość modlitewnego i pokutnego wsparcia wiernych z ich Kościołów w Polsce ${ }^{32}$.

Koniecznie należy dodać, że to pozytywne współbrzmienie idei i wydarzenia Soboru z przeżywaną Wielką Nowenną spotykało się z wielkimi grzechami i zagrożeniami, jakich doświadczał w tym czasie katolicki Kościół w Polsce. W pismach biskupów polskich uwidoczniło się to w mocnych słowach sprzeciwiających się laicyzacji i ateizacji, widocznej najbardziej w zwalczaniu katechizacji, zaplanowanej i realizowanej odgórnie bardzo gorliwie

32 Istotne są słowa z niniejszego listu o zaangażowaniu wiernych: „Różne były postacie tego uczestnictwa i współpracy w poszczególnych krajach. Źródłem pociechy i słusznej dumy dla biskupów polskich była świadomość, że Polska modląca się i pokutująca, zjednoczona w wysiłku i trudzie «Zwycięstwa nad sobą na rzecz Soboru», wysunęła się zdecydowanie na czoło i nie pozwoliła się nikomu wyprzedzić w swym głęboko religijnym zainteresowaniem Soborem i w swej ofiarnej z nim współpracy. Świadczyły o tym diecezjalne i parafialne pielgrzymki na Jasną Górę i nieprzerwanie, dzień i noc trwające błagania w intencji Soboru. Świadectwem tego były nabożeństwa soborowe we wszystkich parafiach, kościołach i kaplicach zakonnych, niezliczona ilość Komunii świętych oraz aktów mężnego zwyciężania siebie dla zwycięstwa Kościoła i Chrystusowej sprawy. Warto tu zaznaczyć, że z roku na rok widać wzrastającą miłość do Kościoła i coraz większe zrozumienie jego istoty i posłannictwa w wierzącym społeczeństwie polskim. Mówią o tym cyfry, szczególnie wyraźne w statystykach jasnogórskich. O ile podczas trwania pierwszej sesji liczba delegatów parafii na Jasną Górę wynosiła około 40 tysięcy, a podczas drugiej sesji około 70 tysięcy, w tym roku podczas trzeciej sesji liczba ta przekroczyła 120 tysięcy! Uderzał liczny udział młodych mężczyzn, dzień i noc trwających na modlitwie za Kościół Boży. Niezwykle spisało się nasze ofiarne duchowieństwo, które oprócz organizowania modlitwy soborowej w parafiach, podążało na Jasną Górę, aby wraz ze swymi wiernymi brać udział w czuwaniach dziennych i nocnych przed cudownym obliczem naszej Matki i Królowej, w duchu pokuty i ofiary, dzień i noc służąc Ludowi Bożemu w konfesjonale. Przez 3 miesiące modlitwy soborowej na Jasnej Górze było codziennie około 100 Mszy świętych" (tamże, s. 368). 
i brutalnie przez aparat władzy państwowej ${ }^{33}$. Wielką przeszkodą były liczne apostazje kapłanów i gorszący sposób życia wielu $\mathrm{z}$ nich ${ }^{34}$. Najboleśniej uwidoczniło się to w postępującym rozkładzie życia małżeńskiego i rodzinnego oraz we wzrastającej liczbie zabijanych dzieci nienarodzonych ${ }^{35}$. Przykładem mogą być słowa biskupów z 18 grudnia 1964 roku przeznaczone na uroczystość Świętej Rodziny: „Wstyd i przerażenie ogarnia nas, gdy czytamy w urzędowych publikacjach, że Polska pod względem ilości rozwodów - już po pierwszym roku małżeństwa - wysuwa się na czoło, a liczba dzieci zabijanych przed urodzeniem przekracza pół miliona rocznie! Nie pocieszajmy się tym, że kryzys rodziny ma zasięg ogólnoświatowy, bo zło bardziej rozpowszechnione nie staje się przez to mniejsze, przeciwnie, zmusza do silniejsze-

33 Zob. Orędzie Episkopatu Polski [o obronie katechizacji] „Do rodziców katolickich" (czerwiec 1958) (LPEP, s. 179); List Episkopatu Polski do dzieci Bożych Kościoła Chrystusowego „O aktualnych niebezpieczeństwach” (4.09.1960) (LPEP, s. 209-214); List pasterski biskupów polskich do rodziców, dzieci i młodzieży katolickiej „O nauczaniu prawd wiary świętej” (2.09.1961) (LPEP, s. 232-236); Wezwanie biskupów polskich do modlitwy [ateizm jest grzechem] „Na uroczystość Zesłania Ducha Świętego" (15.04.1962) (LPEP, s. 256-260); Wspótczesna laicyzacja (czerwiec 1962) (LPEP, s. 261-269); Orędzie biskupów polskich do kapłanów, rodziców, dzieci i młodzieży „W sprawie wychowania religijnego” (marzec 1963) (LPEP, s. 288-290); Biskupi polscy do braci kapłanów [o atakach na Kościót] (28.08.1963) (LPEP, s. 296-313); Odezwa biskupów polskich „Do duchowieństwa” (28.08.1963) (LPEP, s. 324-315); Odezwa biskupów polskich „Do rodziców katolickich” (28.08.1963) (LPEP, s. 316); Orędzie biskupów polskich do kapłanów i wiernych "O prawie do nauczania religii” (28.08.1963) (LPEP, s. 317-320).

34 Zob. Biskupi polscy do kapłanów (4.09.1960) (LPEP, s. 203-208); Episkopat Polski do duchowieństwa rzymskokatolickiego w Polsce (15.03.1961) (LPEP, s. 225-231); List Episkopatu Polski do kapłanów „O społecznej kulturze kapłańskiej" (styczeń 1962) (LPEP, s. 245-255); Słowo pasterskie do kapłanów „O niebezpieczeństwie zeświecczenia życia kapłańskiego” (12.09.1962) (LPEP, s. 270-273).

35 Zob. List pasterski Episkopatu Polski [nie zabijaj] „Na Wielki Post 1960 roku", w: LPEP, s. 191-195. 
go wołania na alarm"36. Wobec tych faktów potrzeba też wsparcia z myśli odbywającego się Soboru, który ukazuje Kościołowi sposoby „odnowienia i przystosowania Kościoła do współczesnych warunków" ${ }^{37}$.

Przed wyjazdem na czwartą sesję II Soboru Watykańskiego w liście pasterskim do duchowieństwa i wiernych z dnia 23 czerwca 1965 roku biskupi Kościoła katolickiego w Polsce skierowali następujące wezwanie: „W niedługim czasie my, biskupi Wasi, udamy się do Rzymu, aby wziąć udział w czwartej i ostatniej sesji Soboru Watykańskiego Drugiego. 14 września, w dniu Podwyższenia Krzyża Świętego, Ojciec Święty Paweł VI dokona w bazylice Piotrowej otwarcia sesji soborowej. We wszystkich kościołach naszych rozbrzmiewać będzie wtedy Veni Creator, upraszając dary Ducha Świętego dla biskupów katolickich całego świata, zgromadzonych przy Głowie Kościoła Chrystusowego. Zapraszamy Was, Dzieci najmilsze, do jak najliczniejszego udziału w tym nabożeństwie. Znając Waszą miłość do Kościoła, zrozumienie jego zadań i prac zmierzających do odnowy wszystkiego w Chrystusie, pragniemy Was wezwać do większej jeszcze modlitwy, ofiary i wysiłku na rzecz Soboru, podobnie jak czyniliśmy to w latach ubiegłych. Na apel biskupów polskich stawaliście zawsze do pomocy Soborowi, budząc podziw całego świata, a naszą najwyższą wdzięczność. Gdy Sobór podczas pierwszej sesji rozważał problem reformy liturgii, a więc modlitwy publicznej Kościoła, Wy, wierne Dzieci, dniem i nocą czuwaliście na modlitwie w «Czuwaniach soborowych z Maryją Jasnogórską» [...]. Ekumeniczne założenia i prace Soboru, zmierzające do zjednoczenia chrześcijan w duchu modlitwy Chrystusa - «Spraw, Ojcze, aby byli jedno», wspieraliście «Soborowym czynem dobroci». Gdy podczas trzeciej sesji Sobór rozważał naukę o Kościele, Polska

${ }^{36}$ List pasterski biskupów polskich na uroczystość Świętej Rodziny, w ósmym roku Wielkiej Nowenny „O polskiej rodzinie katolickiej”, w: LPEP, s. 375.

37 Tamże, s. 379. 
podjęła «Zwycięstwo nad sobą za zwycięstwo Kościoła» ${ }^{38}$. Owoce tych modlitw, ofiar i wysiłków zna w pełni sam Bóg"39.

Do tego wezwania biskupi w tymże liście dodali istotną teologiczno-duszpasterską informację: „Dzieci najmilsze! Zwróćcie uwagę na przedziwną zbieżność pracy i założeń Soboru z pracami i założeniami Wielkiej Nowenny. Jest to widoczne w zasadniczym celu Soboru, którym jest odnowa duchowa w Kościele dostosowana do potrzeb współczesnych, oraz w zasadniczym celu Wielkiej Nowenny, zmierzającej do odnowy i moralnego odrodzenia Narodu na progu Tysiąclecia naszego chrześcijaństwa"40.

\section{Recepcja posoborowa}

Spotkanie Wielkiej Nowenny z II Soborem Watykańskim od czasu jego ogłoszenia przez papieża Jana XXIII, jak i podczas ich trwania jest $\mathrm{w}$ istocie właśnie prawdziwą recepcją. Właściwa recepcja zawiera w sobie dwa istotne elementy. Pierwszym jest poprawnie odczytana treść dokumentów soborowych zarówno według litery, jak też i ducha tradycji Kościoła ${ }^{41}$. Drugim, co w niniejszym wystąpieniu jest istotniejsze, jest praktyczne wcielanie wskazań Soboru we wspólnocie kościelnej we wszystkich prze-

38 Wezwanie to zostało zawarte w Liście pasterskim Episkopatu Polski do duchowieństwa i wiernych "O zwycięstwie nad sobq na rzecz Soboru” (4.09.1964), por. LPEP, s. 359-363.

39 List pasterski biskupów polskich „O pomocy Polski katolickiej dla czwartej sesji Soboru Watykańskiego Drugiego" (23.06.1965), w: LPEP, s. 400.

40 Tamże, s. 401.

41 Por. Benedykt XVI w przemówieniu do Kurii Rzymskiej o poprawnej interpretacji II Soboru Watykańskiego, http://sanctus.pl/index.php?grupa=89\&podgrupa=91\&doc=35 [data dostępu: 02.08.2019]; także J. Morawa, Problem hermeneutyki tekstów Vaticanum II, w: Kiedy się zgromadzi cały Kościół, red. J. Morawa, A. Napiórkowski, Kraków 2005, s. 141-155; A. Proniewski, Kościół a świat. Recepcja i aktualność myśli Soboru Watykańskiego II, „Rocznik Teologii Katolickiej” 5 (2006), s. 119-130. 
jawach jej życia. Ale nad tym wszystkim unosi się istotne pytanie, czy jest jakiś idealny model tej recepcji i po czym można go rozpoznać? Recepcja żyje swoim własnym życiem w konkretnej posłudze Kościoła w danej wspólnocie, w której realizuje się jego posłanie. A w tym wypadku modele ocen teoretycznych, choć są nieodzowne, okazują się na ogół niewystarczające, aby uchwycić całość problemu.

Plan recepcji w Kościele powszechnym. W przestrzeni Kościoła powszechnego w pierwszych dwudziestu latach po Soborze wskazuje się trzy fazy jego recepcji: fazę entuzjazmu, fazę rozczarowania i fazę realizmu ${ }^{42}$. Najpierw, zwłaszcza w wielu kręgach na Zachodzie, mówiło się o pierwszym etapie recepcji, zwanym też fazą uniesienia i entuzjazmu, związanym z bezpośrednim wpływem Soboru jako wydarzenia wyzwalającego ${ }^{43}$. Praktyczne, rozczarowujące wyniki wielu poczynań tej fazy recepcji ${ }^{44}$ objawiły się falą krytyki wielu teologów i środowisk kościelnych pod adresem zarówno papieża, jak i tekstów soborowych ${ }^{45}$. Podnosiły się głosy oskarżenia czy to o hamujący konserwatyzm, czy nisz-

42 Por. J. Morawa, Die Communio-Kirche als Sakrament des Heils in und für die Welt, Peter Verlag Frankfurt am Main-Berlin-Bern-New York-Paris-Wien 1996, s. 160nn; tenże, Zur Rezeption des II. Vatikanischen Konzils bei Walter Kasper, „Analecta Cracoviensia” XXV (1993), s. 281-305.

43 Por. W. Kasper, Die bleibende Herausforderung durch das II. Vatikanische Konzil. Zur Hermeneutik der Konzilsaussagen, w: tenże, Theologie und Kirche, Mainz 1987, s. 290.

${ }^{44}$ Por. A. Ziegenaus, Eucharistie - Quelle und Höhepunkt des ganzen christlichen Lebens, w: Das eigentlich Katholische, red. W. Brandmüller, Aachen 1997, s. 181nn.

45 Por. H. de Lubac, Sobór. Kolegialność. Nurty około-soborowe, w: tenże, Najnowsze paradoksy, tłum. K. Dybeł, A. Ziarnicki, Kraków 2010, s. 35-53; W. Kasper, Die bleibende, s. 290. A. Skowronek mówi o „posoborowym zagniewaniu z miłości" wielu wielkich teologów, w tym także i Y. Congara, rozczarowanych wytraceniem siły i determinacji w reformie Kościoła, por. A. Skowronek, Promotor reformy w Kościele, w: Leksykon wielkich teologów XX/XXI wieku, red. J. Majewski, J. Makowski, Warszawa 2003, s. 73-80. 
czący progresizm. Prowadziły do coraz większego paraliżu życia Kościoła i do wyniszczającej, także i obecnie, długotrwałej wojny pozycyjnej $^{46}$. Pontyfikat Jana Pawła II uważany jest ogólnie za trzecią, obecnie występującą, realistyczną fazę recepcji ostatniego Soboru. Istotnym przełomem był zwołany przez niego nadzwyczajny Synod Biskupów w Rzymie w 1985 roku w 20-lecie zakończenia Vaticanum II. Zebrani tam pod przewodnictwem papieża ojcowie synodalni potwierdzili w całej rozciągłości aktualność treści Vaticanum II i wskazali na jego recepcję według hasła wziętego z pierwszych słów czterech konstytucji soborowych: Ecclesia (LG) - sub Verbo Dei (DV) - mysteria Christi celebrans (SC) - pro salute mundi (GS) [Kościół (KK) - prowadzony słowem Bożym (KO) - sprawuje misteria zbawienia (KL) - dla zbawienia świata (KDK) $]^{47}$. Jest to wyjściowy klucz interpretacyjny Vaticanum II dla odczytania podanej przezeń nauki o naturze i posłaniu Kościoła ${ }^{48}$. Wielu uważa, że taką dogłębną, jak też i całościową recepcję Soboru widać w całym pontyfikacie Jana Pawła $\mathrm{II}^{49}$.

Debata nad planem recepcji Vaticanum II $w$ Polsce. Także i w debatach polskich teologów tego czasu pojawiły się projekty schematów kluczy, które miały służyć ocenie pełnej recep-

${ }^{46}$ Por. W. Kasper, Die bleibende, s. 290n.

47 Por. Dwudziestolecie Soboru Watykańskiego II, Wrocław 1986; W. Kasper, Kirche - wohin gehst du? Die bleibende Bedeutung des II. Vatikanischen Konzils, Paderborn 1987, s. 34n.

48 Por. W. Kasper, Die Kirche als Mysterium. Was glaubt die Kirche von sich selbst?, w: Fragen in der Kirche und an die Kirche, red. M. Seybold, Eichstätt-Wien 1988, s. 33; R. Groń, Sobór Watykański II, pomyłka czy opatrznościowy krok Kościoła?, https://opoka.org.pl/biblioteka/T/TH/THW/ rg-vaticanum2.html [data dostępu: 2.08.2019].

49 Por. W. Kasper, Kirche - wohin gehst du?, s. 34n.; H.J. Pottmeyer, Johannes Paulus II. und die Verwirklichung des II. Vatikanums - Eine Bilanz auf der Schwelle zum neunen Jahrhundert, w: Tradition und Inniovation. Denkanstöße für Kirche und Theologie, red. W. Geerlings, J. Meyer zu Schlochtern, Paderborn-München-Wien-Zürich 2003, s. 146nn. 
cji Vaticanum II w katolickim Kościele w Polsce. Dla pamięci, ale także i dla uznania tychże przemyśleń należy przykładowo przytoczyć projekt, który po zakończeniu wspomnianego nadzwyczajnego Synodu Biskupów w Rzymie przedłożył 28 listopada 1985 roku ks. prof. Jerzy Chmiel na sesji naukowej „Sobór Watykański II z perspektywy dwudziestolecia" na Wydziale Teologicznym w Krakowie. Odwołał się do treści teologicznego dwumiesięcznika „Nouvelle Revue Théologique” z 1985 roku i jezuickiego periodyku „La Civiltá Cattolica”, a także do opracowań teologów polskich. Jako biblista przytoczył logion Jezusa zapisany u wszystkich synoptyków: „Nikt młodego wina nie wlewa do starych bukłaków" (Mk 2,22; por. Mt 9,17; Łk 5,38). Wskazał 22 tematy, podzielone na pięć płaszczyzn życia Kościoła w Polsce, na których należałoby skrupulatnie przeprowadzić badania recepcji Vaticanum II:

„1. Nauczanie biskupów i ustawodawstwo kościelne [...].

2. Drugą płaszczyzną jest recepcja teologiczna w szerokim tego słowa znaczeniu, a więc $\mathrm{w}$ rozumieniu ścisłym dyscyplin teologicznych, jak również publicystyki teologicznej, ponieważ komentarze do uchwał soborowych były przeznaczone do szerokiego użytku wiernych, a nie tylko specjalistów [...].

3. Następną płaszczyzną analizy recepcji soborowej jest duszpasterstwo [...].

4. Nie ulega kwestii, że wpływ Soboru daje się odczuć w dziedzinie kultury chrześcijańskiej [...].

5. Ostatnią wreszcie płaszczyzną proponowanych badań recepcji soborowej w Polsce może być płaszczyzna stosunków społecznych. O ile poprzednie płaszczyzny odnosiły się raczej do Kościoła na wewnątrz - ad intra, to obecna ma na względzie relację ad extra - na zewnątrz Kościoła [...]"50.

50 J. Chmiel, Program badań recepcji Vaticanum II w Polsce. Pakiet propozycji, https://www.researchgate.net/publication/324443173_Program_badan_recepcji_Vaticanum_II_w_Polsce_Pakiet_propozycji [data dostępu: 3.06.2019]. 


\section{Recepcja Vaticanum II w Polsce}

Zebrani na uroczystościach milenijnych we Wrocławiu 16-17 października 1966 roku biskupi polscy wystosowali orędzie do Kościoła katolickiego w Polsce na temat jego zadań wynikających z przeżycia Wielkiej Nowenny i dziedzictwa Vaticanum II. Są tam następujące słowa: „Na milenijnym fundamencie będziemy w sposób niewzruszony budować posoborowy Kościół Chrystusowy. Nie dozwólcie, Bracia drodzy, zwodzić się żadnymi zafałszowanymi pozorami. Zapoznajcie się z autentyczną nauką soborową i strzeżcie się przed błędnymi interpretacjami Soboru, przypisywanymi Kościołowi. Są tacy, którzy przeinaczają Sobór, choć podszywają się pod nasze imię. Ci ludzie szkodzą Kościołowi i wyrządzają krzywdę Ludowi Bożemu. Ideały chrześcijańskiego Millennium w Polsce nie są obce rzeczywistym założeniom soborowym. Millennium i Sobór, to w znacznej mierze rzeczywistości zbieżne, pokrewne. Millennium pomagało wzniecić nową chłonność na treść Soboru. Wielka Nowenna, która wiodła nas do Tysiąclecia, wysunęła niemal te same palące zagadnienia duszpasterskie, które wysunął Sobór. Pragniemy zawsze wielkość Soboru podkreślać [...]. Uczyliśmy się i niemal codziennie uczymy się wierności Kościołowi. Dzień w dzień zdajemy egzamin z tej wierności. Stąd też soborowy nakaz pogłębiania świadomości życia w Kościele nie jest dla nas rzeczą obojętną. Razem z całym Kościołem widzimy potrzebę odnowy, odrodzenia. Nauka wydobyta $z$ rozważań milenijnych oddaje nam wszystkim korzystne pomoce i wskazania. Ta nauka wypróbowana, zahartowana w duchowych zmaganiach chrześcijańskiego narodu, została przez Kościół soborowy poświadczona. Zawarta w niej moc i mądrość Chrystusowa objawia się na granicy dwóch tysiącleci jako ratunek współczesnego świata" ${ }^{11}$.

51 Orędzie biskupów polskich do duchowieństwa diecezjalnego i zakonnego „O zadaniach posoborowych Kościoła i o jego położeniu w Polsce” (17.10.1966), w: LPEP, s. 459-460. 
Można się zapytać, jak te wspomniane wyżej modele recepcji Vaticanum II, ten minimalny z Synodu Biskupów w Rzymie, jak $\mathrm{i}$ ten rozbudowany $\mathrm{z}$ medytacji polskiego teologa ${ }^{52}$, mogą być stosowane do diagnozy recepcji w Kościele katolickim w Polsce w powiązaniu z Wielką Nowenną, z jej konkretną treścią i sposobem jej przeprowadzania. Chodzi tutaj najpierw o to, jak były w przestrzeni ogólnopolskiej „soborowo” aktualizowane tematy na każdy rok nowenny. Można by się też zapytać, na ile ta „soborowość" była wykorzystywana na poszczególnych nabożeństwach w parafiach z racji peregrynacji kopii obrazu Matki Bożej Częstochowskiej, gdzie punktem centralnym była Eucharystia często celebrowana przez księdza biskupa. Liturgia ta była poszerzona o rekolekcje lub misje, prowadzące do sakramentu pokuty i do pojednania $\mathrm{z}$ bliźnimi. Trudno $\mathrm{w}$ takim wypadku myśleć szkolnymi kategoriami rozważań teologicznych czy pastoralnych na temat stosowania konkretnych modeli recepcji. Trzeba zacząć od tego, co w tradycji teologicznej nazywano reductio in misterium, czyli znalezienia punktu wyjścia i dojścia, a co może być w życiu całego Kościoła - w pewnym sensie - odniesione do znaczenia liturgii, nade wszystko eucharystycznej, jako szczytu i źródła chrześcijańskiego życia ${ }^{53}$. Po prostu chrześcijanie żyją łaską darów sakramentalnej liturgii, nade wszystko Eucharystią,

52 Kardynał Jean-Marie Lustiger widział wykorzystanie bogactwa Vaticanum II jako propozycję Kościoła dla odnowienia świata cierpiącego na bezsens ateizmu, reformę liturgiczną dla wzbogacenia i ochrony różnych kultur ludów na ziemi, zaś ustrój Kościoła jako model tworzenia ponadnarodowej wspólnoty ludów świata, por. J.-M. Lustiger, Sobór Watykański II. O „nowq epokę historii ludzkiej”, „W drodze”, 11-2/147-148 (1985), s. 7-16.

53 Por. S. Zatwardnicki: „Wszystkie tajemnice - [wg H.U. von Balthasara] - mają być zatem odnoszone do całości zawsze większej od sumy poszczególnych tajemnic wiary, a także zakorzeniane w centralnej tajemnicy Chrystusa (tzw. zasada reductio in Mysterium)", https://blogownia.stacja7.pl/index.php/hierarchia-prawd-ktora-sluzy/ [data dostępu: 23.07.2019]. 
która jest właśnie tym fundamentalnym punktem wyjścia i dojścia. Wielu znawców problemu wskazuje, że nie przypadkowo Vaticanum II rozpoczął swoje dzieło od ogłoszenia reformy liturgicznej, która była swoistym spiritus movens dla dalszego przebiegu dzieła soborowego (por. KL 10). I choć Sobór ostatecznie nie podał gotowych rozwiązań aktualnych problemów Kościoła, to właśnie w liturgii położył fundament i wskazał na źródło ich rozumienia. Bo to w liturgii, w której dokonuje się uobecnienie misterium zbawienia, na każdym etapie swego życia Kościół rozpoznaje najpełniej tajemnicę swego powiązania z Jezusem Chrystusem $^{54}$.

Moment ogłoszenia zwołania Vaticanum II był w Polsce czasem „licznego, wręcz tłumnego udziału we mszach niedzielnych, rekolekcjach parafialnych, licznych spowiedzi pierwszo-piątkowych czy rekolekcyjnych [...]. W czasie trwania Soboru docierały do nas pewne informacje o sposobie i toku jego prac nad problemami, które zostały wyłonione jako podstawowe pole dyskusji i prac redakcyjnych. Na pierwszym miejscu postawiono to, co stanowi o istocie życia Kościoła - liturgię. Wcześniejsze ożywienie zainteresowania liturgią i ruchy zmierzające do jej odnowy przygotowały w Kościele podatny grunt dla realizacji pierwszego dokumentu Soboru, jakim stała się Konstytucja o liturgii świętej Sacrosanctum concilium, ogłoszona 4 grudnia 1963 r." 55.

Bez podejmowania szczegółowych analiz dla zrozumienia procesu recepcji Vaticanum II w Polsce należy zwrócić uwagę na dwa istotne problemy. Pierwszym jest zauważenie faktu, iż nabożeństwa Wielkiej Nowenny były przesycone tzw. ludową religijnością. Faktycznie ona je niosła i równocześnie ubogacała się o nowe formy i teksty, a także znaki i symbole. W takim też charakterze następowało spotkanie ze wskazaniami

54 Por. S. Araszczuk, Recepcja konstytucji o liturgii w Polsce, transkrypt, https://docplayer.pl/7358073-Recepcja-konstytucji-o-liturgii-wkosciele-w-polsce.html [data dostępu: 21.07.2019].

55 J. Bagrowicz, Recepcja Soboru, s. 587. 
Vaticanum II. Charakter tego spotkania określił owocność recepcji Soboru w katolickim Kościele w Polsce ${ }^{56}$. Drugim sposobem oceniania owoców recepcji reformy liturgicznej w powiązaniu z Wielką Nowenną jest zauważenie ewolucji katechetycznych formuł moralnych, wpajanych od pokoleń wiernym. A chodzi o proces przyswojenia ewolucji katechetycznych formuł moralnych, według których:

- na początku było przykazanie o pobożnym wysłuchaniu mszy św.,

- następnie, aby we mszy św. nabożnie uczestniczyć,

- aż do zalecenia przez Sobór, aby mszę św. w pewnym sensie współsprawować ${ }^{57}$.

W tym przypomnieniu i wskazaniu odsłania się zadanie długiego i permanentnego procesu ewangelizacyjno-katechetycznego, który obejmie możliwie wszystkich uczestników Eucharystii i doprowadzi ich do czynnego uczestnictwa w liturgii eucharystycznej. Wielką pomocą było od 7 marca 1965 roku dopuszczenie języka polskiego w czytaniach i obrzędzie Komunii św. We wzbogaceniu przestrzeni i czasu liturgii - jak mówią liturgiści z pewnością mogły do pewnego stopnia pomóc zmienione obrzędy jej sprawowania. Jednak zawsze pozostaje pytanie, czy do ich

56 Temat ten wymaga osobnego studium. Wspomina o nim, jednakże bez odniesienia do Wielkiej Nowenny, S. Araszczuk w opracowaniu pt. Język i formy pobożności ludowej, „Seminare. Poszukiwania naukowe” 20 (2004), s. 163-179.

57 Tak to zaleca Sobór: „Kościół zatem bardzo się troszczy o to, aby chrześcijanie w tym misterium wiary nie uczestniczyli jak obcy lub milczący widzowie, lecz aby przez obrzędy i modlitwy misterium to dobrze rozumieli, w świętej czynności brali udział świadomie, pobożnie i czynnie, byli kształtowani przez słowo Boże, posilali się przy stole Ciała Pańskiego i składali Bogu dziękczynienie; aby ofiarując niepokalaną Hostię nie tylko przez ręce kapłana, lecz także razem z nim, uczyli się ofiarowywać samych siebie i za pośrednictwem Chrystusa z każdym dniem doskonalili się w zjednoczeniu z Bogiem i wzajemnie ze sobą, aby ostatecznie Bóg był wszystkim we wszystkich" (KL 48); por. B. Nadolski, Eucharystia. Jej miejsce i rola w życiu chrześcijanina, Kraków 2006, s. 75. 
zdynamizowania przyczyniło się „odwrócenie ołtarza” i stanięcie „twarzą w twarz” celebransa $\mathrm{z}$ wiernymi ${ }^{58}$ Podstawowym wyznacznikiem oceny jest udział wiernych w Eucharystii i rozumienie przyjmowanych sakramentów. Jest to z pewnością niekończący się proces, aktualny także dziś i na jutro Kościoła. Odpowiedź jest w każdej celebracji eucharystycznej i innych czynnościach liturgicznych, sprawowanych w świątyniach katolickich w Polsce. Powstają też liczne pytania skierowane do fachowców liturgistów, m.in. jak ma wyglądać idealna liturgia - w duchu i prawdzie - sprawowana według postanowień Vaticanum II? I po wtóre: co należy czynić, aby taka idealnie spełniana liturgia przyciągała i aby wychodzący z niej ludzie czuli się prawdziwie ubogaceni? ${ }^{59}$

Świadek tego czasu notował: „Wśród wielkich akcji duszpasterskich [w okresie Wielkiej Nowenny] na specjalną uwagę zasługuje sposób recepcji przez Kościół polski tak niezmiernie ważnych dla Kościoła powszechnego postanowień II Soboru Watykańskiego (1962-1965). Ze strony niecierpliwych intelektualistów katolickich zgłaszano wówczas pod adresem prymasa i episkopatu szereg zastrzeżeń co do powolności tej recepcji. Rzeczywiście w Polsce ze spokojem realizowano przede wszystkim program Wielkiej Nowenny, później zaś stopniowo, latami, krok po kroku, po dłuższej akcji przygotowawczej wprowadzono w praktyce życia religijno-liturgicznego jedną zmianę po drugiej. Uderza tu różnica w porównaniu z postępowaniem w wielu krajach zachodnich, gdzie często biskupi i kler zmieniali dosłownie z dnia na dzień ustalone zwyczaje liturgiczne i nawet wygląd kościoła, raniąc tym samym wielu wiernych i powodując często bardzo poważny kryzys. W praktyce polskiej uderza, obok powolności, chęć maksymalnego poszanowania dla tradycji i przyzwyczajeń wiernych, wprowadzanie zmian na ogół nie wywoływało oporów, przeciwnie, szybko zauważono i doceniono wręcz edukacyjne chociażby wprowadzenie języka polskiego do rytu

${ }^{58}$ Por. B. Nadolski, Eucharystia, s. 8.

59 Por. tamże, s. 58nn. 
mszy św. (29 XI 1970, w pierwszą niedzielę adwentu) czy rytów sakramentów i obrzędów"60.

Znawca historyk podsumowuje: „W Polsce powoli wdrażano uchwały soborowe. Uniknięto napięć i wewnętrznego rozbicia, tak bolesnego w niektórych krajach zachodnich. Idee odnowy upowszechniały wydane po polsku dokumenty Soboru ${ }^{61}$. Mówiono o nich na sympozjach i kursach duszpasterskich, pisano w książkach i artykułach, a zwłaszcza w seryjnym wydawnictwie [...]. Reformę liturgiczną przyjęto bez zbiorowych protestów, nawet gdy język polski zajął miejsce łaciny, co nie podobało się jednostkom z inteligencji katolickiej. Kapłani natomiast uważali, że zbyt długo przygotowywano wydanie brewiarza w języku polskim"62.

Po wielu latach papież Jan Paweł II, uczestnik Vaticanum II, zaangażowany w szczególny sposób w przebieg Wielkiej Nowenny, powie, że „ «reforma liturgiczna Soboru» w znacznym stopniu przyczyniła się do bardziej świadomego, czynnego i owocniejszego uczestnictwa wiernych w Najświętszej Ofierze ołtarza. Ponadto w wielu miejscach «adoracja Najświętszego Sakramentu» znajduje swoją właściwą rolę w życiu codziennym i staje się niewyczerpanym źródłem świętości. Pobożne uczestnictwo wiernych w procesji eucharystycznej w uroczystość Ciała i Krwi Pańskiej jest łaską od Pana, która co roku napełnia radością wszystkich biorących w niej udział. Można by dalej wymieniać inne pozytywne przykłady wiary i miłości do Eucharystii" ${ }^{63}$.

60 J. Kłoczowski, L. Müllerowa, W dwudziestym stuleciu (1918-1980), s. 402-403.

${ }^{61}$ Por. Sobór Watykański II. Konstytucje, dekrety, deklaracje, tekst łacińsko-polski, Wydawnictwo Pallottinum; opracowanie przygotowane z polecenia ks. kard. Karola Wojtyły przez ośrodek krakowski, redaktorami naukowymi byli ks. bp Julian Groblicki i ks. Eugeniusz Florkowski (tłumacz Lumen gentium i autor zamieszczonego tam wstępu), imprimatur do wydania podpisali 5 października 1967 r. ks. kard. Karol Wojtyła i ks. Stefan Marszowski, wicekanclerz Kurii Metropolitalnej.

62 M. Banaszak, Historia Kościoła, s. 311.

63 Jan Paweł II, Ecclesia de Eucharystia (7.04.2003), s. 10. 


\section{Wątek mariologiczny}

Mariologia Vaticanum II stanowi temat bogaty zarówno w rozważania teologiczne, jak też w wątki duszpastersko-katechetyczne i duchowe. A źródłem tego jest VIII rozdział Konstytucji dogmatycznej o Kościele Lumen gentium ${ }^{64}$. Przy jego analizie chodzi najpierw o przebieg dyskusji soborowej nad jego treścią i kształtem, a także o wątki okołosoborowe, czego świadectwem jest ogłoszenie przez papieża Pawła VI na zakończenie III sesji II Soboru Watykańskiego, 21 listopada 1964 roku, Maryi Matką Kościoła.

Pomijając całą treść bogactwa rozważań ojców soborowych, zawartą w dokumencie maryjnym i w komentarzach dotyczących wspomnianego VIII rozdziału Lumen gentium, pożyteczne i pouczające będzie wspomnienie myśli ks. kard. Stefana Wyszyńskiego na temat tej sprawy. Jest to tym bardziej potrzebne, gdyż nierzadko uważa się jego mariologię za przejaw jego osobistego - i bardzo subiektywnego - nabożeństwa do Najświętszej Maryi Panny, zaś teologów i myślicieli katolickich mających alergię antymaryjną przeraża fakt, iż ta właśnie prymasowska maryjność zaznaczyła tak mocny ślad w tzw. polskim katolicyzmie. A dowodem tego ma być treść Wielkiej Nowenny jego autorstwa, związana $\mathrm{z}$ ideą niewolnictwa maryjnego ${ }^{65}$.

${ }^{64}$ Por. L. Szewczyk, Recepcja mariologii Vaticanum II w polskiej teorii i praktyce homiletycznej, „Salvatoris Mater” 16/1/4 (2014), s. 276-287. Artykuł jest zbyt ogólnikowy, ale zawiera bogatą bibliografię na temat myśli mariologicznej w Polsce po Vaticanum II.

65 Por. K. Wojtyła, Komentarz do milenijnego Aktu oddania się Maryi Królowej Polski, w: Jej zawierzył Kościół i Naród, red. W. Moroz, Warszawa 1984, nawiązanie do VIII rozdz. LG s. 52; A. Proniewski, Błogosławiona Dziewica Maryja Matka Boga w misterium Chrystusa i Kościoła. W pięćdziesiątą rocznicę Konstytucji dogmatycznej o Kościele „Lumen gentium”, „Studia Koszalińsko-Kołobrzeskie” 22 (2015), s. 131-143; A. Kubiś, Geneza pojęcia Kościót-Sakrament w konstytucji dogmatycznej o Kościele, „Analecta Cracoviensia” X (1978), s. 268 n. 
Temat ten, idea niewolnictwa Maryi i jego wyjaśnienia na bazie inspiracji VIII rozdziału Lumen gentium, jest osobny i wymaga odrębnej analizy ${ }^{66}$.

Kardynał Stefan Wyszyński, inicjator i propagator Wielkiej Nowenny Milenijnej, uczestniczył aktywnie w pracach II Soboru Watykańskiego, począwszy od komisji przygotowawczej i sekretariatu Extra Ordinem, do członkostwa w prezydium Soboru od II sesji ${ }^{67}$. Zabierał głos na dziesięciu sesjach generalnych, między innymi w sprawie tekstu maryjnego. Przeciwny był, ku zdumieniu wielu, tworzeniu osobnego dokumentu soborowego o Matce Bożej. Był zwolennikiem ścisłego powiązania treści mariologicznych z eklezjologicznymi ${ }^{68}$. Świadczą o tym jego słowa: „Zdaje się niemal do cudów należy zaliczyć fakt, iż nauka o Matce Bożej znalazła się w Konstytucji dogmatycznej o Kościele - mariologia - w eklezjologii! Znając zakulisy sprawy i tok dyskusji, jest to zdumiewające. Różne wypowiedzi stanowiły raczej odskocznię dla pobudzenia uczuć Ojców Soborowych, którzy domagali się, aby tam, gdzie mówi się o misterium Kościoła - Chrystusie, Bogu Wcielonym, żyjącym w Kościele, mówić również o Jego Matce. Atmosfera posoborowa nie uchwyciła tego należycie. Nie brak jeszcze dzisiaj ludzi, dla których jest to szokujące. Przecież mamy dokument, który mówi o obecności Maryi w misterium Chrystusa i Kościoła. Nazwano Ją «prototypem Kościoła», czego dotąd - poza pismami różnych teologów - w oficjalnej nauce Soboru nie było" 69 .

66 Obszernie na ten temat zob. List pasterski biskupów polskich „O pomocy Polski katolickiej dla czwartej sesji Soboru Watykańskiego Drugiego” (23.06.1965), w: LPEP, s. 400nn.

67 Por. K. Wojtyła, Znaczenie Kardynała Stefana Wyszyńskiego dla współczesnego Kościoła, „Zeszyty Naukowe KUL” 3 (1971), s. 27-31.

${ }^{68}$ Por. K. Wojtyła, Udział biskupów polskich w Soborze Watykańskim II, „Wiadomości Archidiecezjalne Warszawskie" 5 (1971), s. 40-46; tenże, Vaticanum II. Czas twórczego myślenia. Wypowiedzi soborowe, Rzym 2014, s. 87n.

69 S. Wyszyński, Jasnogórskie wspomnienia. Zapiski osobiste, Częstochowa 2018, s. 321. 
Wystąpienia kard. Wyszyńskiego były wyrazem postawy polskiego episkopatu, w którego imieniu złożył on memoriał na ręce Pawła VI, prosząc o ogłoszenie Maryi Matką Kościoła. Tok myślowy memoriału zgodny był z ideą prymasa, obecną w jego przepowiadaniu jeszcze przed Soborem, podkreślającą nieustanną obecność Maryi, Matki Jezusa, w życiu Kościoła. „Maryja jest nie tylko rozdziałem w teologii - powtarzał prymas - nie tylko postacią historyczną, która wypełniła swoje zadanie i przeszła do archiwum, ale jest aktualnie czynna"70.

To, że dla wielu teologów stwierdzenia z VIII rozdziału Lumen gentium były wyważoną mariologią $\mathrm{w}$ wymiarze chrystotypicznym i eklezjotypicznym ${ }^{71}$, nie było wystarczające dla ks. prymasa. Dla niego ostatecznie miała to być mariologia Kościoła zaangażowanego w konkretną posługę dla wspólnoty Kościoła i pojedynczego wierzącego. Można powiedzieć, że chodzi tutaj o mariologię pastoralną, o obecność Maryi „w misterium Chrystusa i Kościoła na polskiej ziemi”"72, o „Jej obecność w niełatwych dziejach naszego Narodu"73. Przykładem tego był akt zawierzenia Matce Bożej, powiązany z ogromnym wysiłkiem duszpasterskim Wielkiej Nowenny, można powiedzieć - z ewangelicznym przeoraniem Polski. Współbrzmiało to - co z mocą podkreślał prymas Stefan Wyszyński i biskupi polscy w listach pasterskich - z pracami II Soboru Watykańskiego, zwłaszcza przez Czuwania Soborowe z Maryją Jasnogórską ${ }^{74}$. Gromadziły się na nich parafie polskie, aby modlitwą, ofiarą i poświęceniem wspierać ojców Soboru. Może nie zawsze zdawano sobie sprawę, iż ta modlitwa

70 Tenże, Kazania i przemówienia autoryzowane prymasa Polski S. Wyszyńskiego (17.02.1966), t. 22, Warszawa 1966, s. 397.

${ }^{71}$ Por. L. Szewczyk, Recepcja mariologii, s. 281n; A. Proniewski, Błogosławiona Dziewica, s. 132n.

72 S. Wyszyński, Jasnogórskie wspomnienia, s. 119.

73 Tamże, s. 126.

${ }^{74}$ Por. J. Tomziński, Jasnogórska Maryja w życiu i służbie Ks. Kard. Stefana Wyszyńskiego, Prymasa Polski, „Studia Claromontana” 2 (1981), s. 20-22. 
jest jednym z przejawów pogłębionej recepcji myśli Vaticanum II. Paweł VI, od początku przychylny propozycji Episkopatu Polski, na zakończenie III sesji II Soboru Watykańskiego, 21 listopada 1964 roku, ogłosił Maryję Matką Kościoła ${ }^{75}$.

W powyżej wspomnianym przekonaniu kard. Stefan Wyszyński będzie wskazywał członkom Instytutu Prymasowskiego i „realistom”76, aby podjęli wysiłek pogłębienia maryjności zaktualizowanej przez Jasnogórskie Śluby Narodu i Akt oddania Maryi w niewolę miłości za wolność Kościoła w oparciu o naukę Vaticanum II, zawartą zwłaszcza w VIII rozdziale Lumen gentium: Błogosławiona Maryja Dziewica Boża Rodzicielka w tajemnicy Chrystusa i Kościoła ${ }^{77}$. Temat ten podjął też na Ogólnopolskim Kongresie Maryjnym (22 maja 1967) na Jasnej Górze, kiedy w kazaniu rozwinął temat obecności Maryi w misterium Chrystusa i Kościoła, wskazując na treść adhortacji Signum Magnum Pawła VI z 13 maja 1967 roku ,jako potwierdzenie naszych wysiłków i naszej drogi, zarówno w dziedzinie teologicznej pracy naukowej, jak i pracy duszpasterskiej. Przecież nasza praca i modlitwa w Polsce idą w kierunku realizacji uchwał Soboru Watykańskiego II, oraz w kierunku pogłębienia zobowiązań Ślubów Jasnogórskich i realizacji Wielkiego Aktu 3 Maja"78.

Teoretyczno-duchowa myśl prymasa, także i mariologiczna, miała zawsze swój finał w praktycznym wskazaniu kościelnym. Po wysłuchaniu wygłoszonego na Konferencji Episkopatu Polski teologicznego uzasadnienia przez kard. Karola Wojtyłę prze-

75 Por. W. Miziołek, Tytuł „Matki Kościoła” przyznawany Najświętszej Maryi Dziewicy i rola Episkopatu Polski w jego ogłoszeniu, „Wiadomości Archidiecezjalne Warszawskie" 5 (1971), s. 46-52; A. Santorski, U źródeł soborowych dyskusji nad relacja Maryi do Kościoła, „Przegląd Powszechny” 10 (1983), s. 9-19.

76 „Szaleńcami” lub „realistami” nazywano osoby z różnych środowisk, podejmujące ideę oddania się Matce Bożej, por. S. Wyszyński, Kazania i przemówienia, s. 108.

77 Por. tamże, s. 140.

78 Tamże, s. 145-146. 
słania Milenijnego Aktu oddania Maryi w niewolę miłości za wolność Kościoła w Polsce i w świecie ksiądz prymas treści te widział jako pomoc w realizowaniu Konstytucji duszpasterskiej o Kościele w świecie współczesnym w wymiarze chrześcijaństwa społecznego $^{79}$.

Orędzie Milenijne do Niemców. Pozostaje, w formie komunikatu, przypomnieć o jeszcze jednym aspekcie recepcji Vaticanum II związanym z Wielką Nowenną Milenijną. Jego znaczenie wychodzi daleko ponad problemy kościelne i staje się inspiracją na płaszczyźnie ogólnoświatowej ${ }^{80}$. A chodzi o orędzie biskupów polskich do biskupów niemieckich z 18 listopada $1965 \mathrm{roku}^{81}$. Polscy biskupi napisali: „Właśnie w czasie Soboru wydaje się nam nakazem chwili, abyśmy zaczęli dialog na pasterskiej platformie biskupiej, i to bez ociągania się, byśmy się nawzajem lepiej poznali - nasze wzajemne obyczaje ludowe, kult religijny i styl życia, tkwiące korzeniami w przeszłości i tą przeszłością kulturalną uwarunkowane. Staraliśmy się przygotować wraz z całym polskim Ludem Bożym na uroczystości Tysiąclecia przez tak zwaną Wielką Nowennę pod wysokim patronatem Najświętszej Maryi Panny [...] Cały wierzący Naród brał też duchowy i bardzo żywy udział w Soborze [...] Prosimy Was, katoliccy Pasterze Narodu niemieckiego, abyście na własny sposób obchodzili z nami nasze chrześcijańskie Millennium: czy to przez modlitwy, czy przez ustanowienie $\mathrm{w}$ tym celu odpowiedniego dnia. Za każdy taki gest będziemy Wam wdzięczni. I prosimy Was też, abyście przekazali nasze pozdrowienia i wyrazy wdzięczności niemieckim Braciom Ewangelikom, którzy wraz z Wami i z nami trudzą się nad znalezieniem rozwiązania naszych trudności. W tym jak

79 Por. tamże, s. 146.

80 Por. J. Morawa, Kościół w Polsce wobec wojny w XX wieku. Aspekt teologiczno-fundamentalny, w: Kościót i dar pokoju, red. J. Morawa, M. Chojnacki, A.A. Napiórkowski, Kraków 2016, s. 246nn.

81 Orędzie biskupów polskich do ich niemieckich braci w Chrystusowym urzędzie pasterskim, Rzym, 18 listopada 1965 r., w: LPEP, s. 829-836. 
najbardziej chrześcijańskim, ale i bardzo ludzkim duchu, wyciągamy do Was, siedzących tu na ławach kończącego się Soboru, nasze ręce oraz udzielamy wybaczenia i prosimy o nie. A jeśli Wy, niemieccy biskupi i Ojcowie Soboru, po bratersku wyciągnięte ręce ujmiecie, to wtedy dopiero będziemy mogli ze spokojnym sumieniem obchodzić nasze Millennium w sposób jak najbardziej chrześcijański"82.

\section{Zakończenie - nadzieja na prawidłową i owocną recepcję}

Słowem zakończenia niech będzie przesłanie polskich ojców Soboru z ostatniej sesji Vaticanum II: „W Polsce wprowadzenie w życie uchwał soborowych spotka się z początkiem drugiego tysiąclecia naszych chrześcijańskich dziejów. Sądząc po tej gorliwości, z jaką, najmilsi, wspomagaliście obradujący Sobór, możemy słusznie oczekiwać równie powszechnego i żarliwego współdziałania w wypełnieniu soborowych wskazań. Uchwały soborowe mają stać się drogowskazem i przynagleniem do gruntownej odnowy w duchu Ewangelii. Zanim przywieziemy Wam, najmilsi, nowe konstytucje i dekrety soborowe, oddajemy nasze obecne prace w macierzyńskie dłonie Maryi i łączymy się z rozmodloną Jasną Górą i z Wami, co w swoich kościołach i kaplicach otaczacie ołtarze i obraz Dziewicy Wspomożycielki. Radujemy się z Waszego udziału w dziele soborowym i wiele sobie obiecujemy po Waszej wytrwałej z nami współpracy"s3.

Wielka Nowenna dobrze współgrała zarówno modlitewnie, jak i mentalnie z wydarzeniem Vaticanum II. „Oswoiła” od samego początku wiernych Kościoła katolickiego w Polsce, choćby

82 Tamże, s. 835-836.

83 List pasterski polskich ojców soborowych „Do katolickiej Polski” (15.10. 1965), w: LPEP, s. 414. 
ogólnie, ze świadomością przynależności do wielkiego organizmu Kościoła Jezusa Chrystusa na ziemi. Przygotowała grunt pod właściwą recepcję jego treści, która to recepcja staje się obecnie jeszcze bardziej konieczna i wyrazista.

\section{The Great Millennium Novena and the reception of Vaticanum II in Catholic Church in Poland}

The appraise of the reception of the Second Vatican Council in the Catholic Church of Poland has to take account of its situation in the post-World War 2 reality. The borders as well as the diocesan boundaries were altered. It was also related to painful experience of World War 2 and to post-war emmigration from East Poland to so-called Western Lands, granted after the war. The work of the Church was focused on integration of those people in the new environment and pastoral ministry amongst them. The new system, imposed on Poland, was hostile to the Church and aimed to complete atheization of the Nation. That is the reason why the shepherds of the Church undertook multiple actions to protect and inspirit Christian faith of the Nation. One of the actions was the Great Novena, prior to the millennial celebrations of the Baptism of Poland. It took place from 1957 till 1966. During that time the Second Vatican Council was taking place in Rome. Polish bishops, who were taking part in the council, were sending messages from the council halls and Polish catholics were praying for the council in their parishes. That is when the true reception, which is familiarising worshippers with Vaticanum II, was started.

During the last part of the council, Polish bishops were writing to Polish catholics: "the implementation of the council's acts will meet the beginning of the second millennium of Christianity in Poland. Going by the fervour, you, dear brothers and sisters, were supporting the debating council, we can truly 
expect equally popular and earnest cooperation in fulfilling the council's postulates. The council's postulates will become a guideline and urgency for thorough renewal in the Gospel. Before we bring you, dear brothers and sisters, new constitutions and the council's acts, we are giving our present work into Blessed Mary's motherly hands and we are joining the absorbed in prayer Jasna Gora and you, who are surrounding altars and our Lady Help of Christians sacred image. We are rejoicing in your participation in the council's work and are very hopeful after your perseverant cooperation with us".

The Great Millennium Novena consorted prayerfully and mentally with the event of Vaticanum II. From the very beginning it "accustomed" the faithful of the Catholic Church of Poland, although generally with affiliation awareness, to the great organism of Jesus Christ's Church on Earth. It was preparing the soil for the reception of its contents, which - the reception - is currently becoming even more essential and pronounced. 